\title{
Testing the coral fragment size-dependent survivorship hypothesis for the calcareous hydrozoan Millepora complanata
}

\author{
John B. Lewis \\ Department of Biology, McGill University, 1205 Dr. Penfield Ave., Montreal, Quebec, Canada H3A 1B1
}

\begin{abstract}
The distribution of living colonies of the calcareous hydrozoan Millepora complanata and broken and reattached millepore fragments was examined in $\mathrm{m}^{2}$ quadrats along line transects on fringing reefs at Barbados, West Indies. Of the broken fragments $35 \%$ reattached, but survival was not found to be size-dependent, in contrast to reports of breakage in Scleractinia. The number of reattached fragments was positively correlated with the total number of fragments and with the number of quadrats containing millepore colonies. It is proposed that fragmentation has a selective advantage because of the high survival rate of fragments and that there should be an advantage to increasing colony size in the population because the risk of breakage increases with colony size.
\end{abstract}

Breakage of coral colonies during storms has been widely reported, and resulting damage to reefs is frequently on a large scale (Highsmith et al. 1980, Tunnicliffe 1980, Woodley et al. 1981, Dollar 1982, Rogers et al. 1982). Breakage appears to be most common in branching species (Highsmith et al. 1980, Tunnicliffe 1980,1981 ) but has also been reported in massive and solitary corals (Highsmith 1980, 1982). Reattachment and regeneration of fragments occur frequently and ameliorate the destructive effects of storms (Highsmith 1982). Indeed, fragmentation is regarded as a natural process (Hughes 1989) and an important mode of asexual reproduction in some species (Highsmith 1980, 1982, Highsmith et al. 1980), and it may enhance propagation over broader habitat ranges (Tunnicliffe 1981).

Survival of coral fragments is strongly size-dependent; large fragments have a greater chance of success than do small fragments (Loya 1976. Highsmith et al. 1980, Hughes 1989). Similar predictions that mortality rates decline with increasing colony size have been made for the survival of sexually produced coral colonies (Connell 1973, Hughes and Jackson 1985, Lewis 1989a). The size-dependent survival hypothesis thus appears to apply for fragments, larval colonizing stages and regenerating older colonies. An opportunity for testing the generality of the survival hypothesis was recognized from observations of loose and attached fragments of the calcareous hydrozoan Millepora complanata Lamarck on reefs at Barbados, West Indies.

Millepora complanata is a common, calcareous hydrozoan on Caribbean reefs and flourishes in high wave-energy environments (Boschma 1948, Lewis $1989 b$ ). These millepores tend to grow so that the faces of the blades or plate-like colonies are presented towards waves and currents (Stearn \& Riding 1973, Lewis 1989b). This appears to be the least mechanically stable orientation for rigid, plate-like forms and likely to increase risk of breakage. Risk of breakage also increases with size (Denny et al. 1985). Thus, breakage of $M$. complanata colonies is likely to occur frequently, and broken fragments were routinely observed in field populations on reefs in Barbados during all seasons. If reattachment of millepores occurs, it might be expected that survival of the fragments would, like hermatypic corals, be size-dependent.

Methods. The abundance and spatial distribution of Millepora complanata were estimated from contiguous $\mathrm{m}^{2}$ quadrats laid out along line transects on 3 reefs on the west coast of Barbados. The reefs were situated within a $3 \mathrm{~km}$ stretch of the northern sector of the west coast which is least affected by eutrophication (Tomascik \& Sander 1985). For each reef, 25 transects were established on the surface of the ridges or spurs making up the reefs (Stearn \& Riding 1973, Stearn et al. 1977). The transects were aligned perpendicular to the shore and spaced at suitable intervals so as to include the full length of the reefs. Five additional transects were sampled for each reef along the grooves or channels between the ridges (Stearn \& Riding 1973, Mah \& Stearn 1986). 
Within each quadrat, the presence or absence of living Millepora complanata colonies was recorded, together with the number of broken millepore fragments and their attachment condition. Reattached colony fragments were distinguished from normal growth colonies by virtue of their irregular shapes, orientation and displaced attachment sites. Fragment sizes $\left(\mathrm{cm}^{2}\right)$ were calculated as the product of the largest dimension (length) and the perpendicular width at the centre of the length.

Results. The spatial distribution of quadrats with Millepora complanata colonies and of colony fragments, in relation to distance from shore, is shown in Fig. 1 for the 3 reefs combined. The frequency of

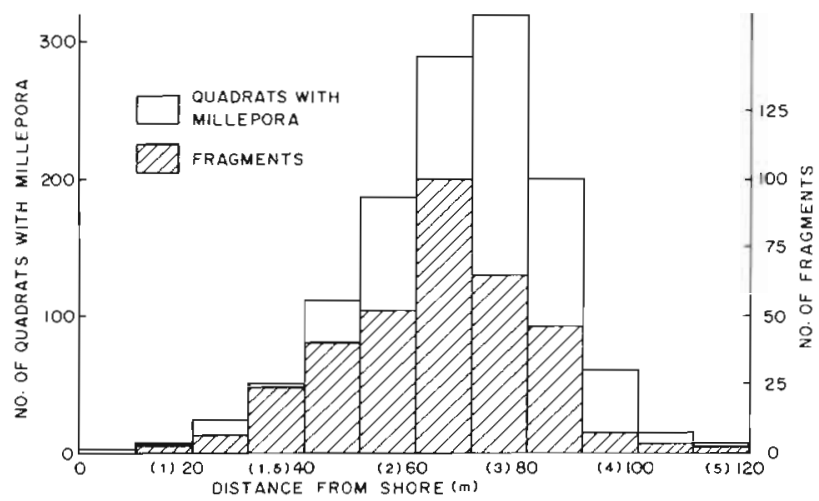

Fig 1 Millepora complanata. Distribution of quadrats containing $M$. complanata colonies and of number of fragments, across fringing reefs at Barbados. West Indies. Depths (m) are shown in parentheses

occurrence of quadrats containing millepore colonies was highest in the region between 60 and $80 \mathrm{~m}$ from the shore and declined both seaward and shoreward The distribution of millepore fragments was similar, with the largest number of fragments occurring between 60 and $70 \mathrm{~m}$. Only a few colonies and a small number of fragments (mean $=5$ transect $^{-1}, \mathrm{n}=15$ ) were found along the reef channels. These were not included in subsequent analyses.

The range of fragment sizes sampled was between 4 and $500 \mathrm{~cm}^{2}$, with a mean size of $90.8 \mathrm{~cm}^{2}$ (SD $=86.1$, $\mathrm{n}=369$ ). Of all fragments sampled on the 3 reefs combined, $35 \%$ were reattached. Less than $1 \%$ of all fragments counted were completely dead and contained no living tissue.

Relationships between the abundance of Millepora complanata colonies (expressed as frequency of quadrats containing colonies along transects) and the abundance of unattached and reattached colony fragments are shown in the regression lines of Figs. $2 \& 3$. The total number of fragments is positively correlated with the number of quadrats containing $M$. complanata

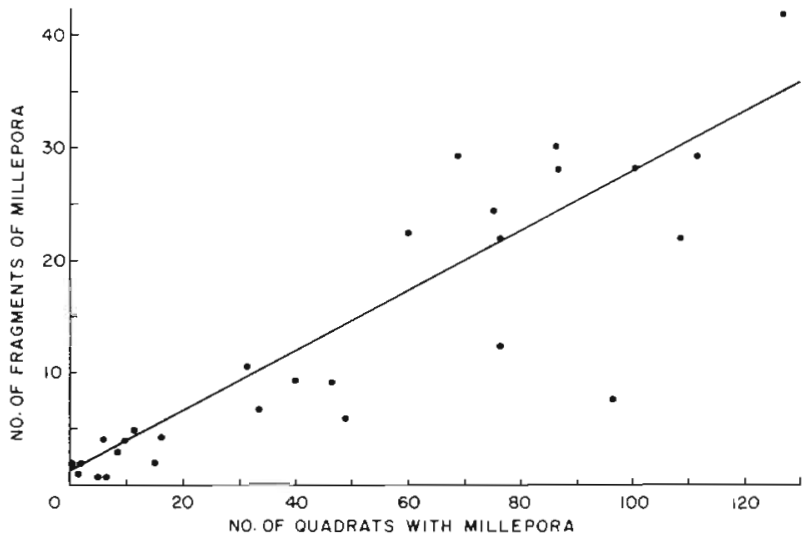

Fig. 2. Millepora complanata. Regression of number of fragments on number of quadrats with millepore colonies. No. fragments $=0.11+0.28 \times$ no. quadrats containing millepore colonies $\left(r^{2}=0.78, n=29\right)$

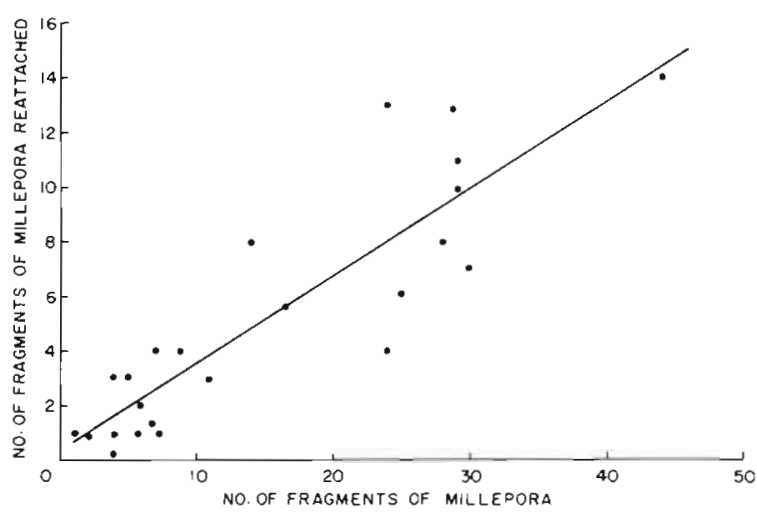

Fig. 3. Millepora complanata. Regression of number of reattached fragments on total number of fragments. No. fragments reattached $=0.52+0.32 \times$ total no. fragments $\left(\mathrm{r}^{2}=0.72\right.$ $n=27$ )

colonies (Fig. 2). The number of reattached fragments is positively correlated with the total number of fragments (Fig. 3). Thus, the number of both free and reattached fragments increases with abundance of millepore colonies.

Neither the regression of percentage of fragments attached (arcsine transformed) on mean fragment size nor that on total number of fragments was statistically significant $\left(r^{2}=0.01, a=34.10, b=-0.04\right.$, and $\mathrm{r}^{2}=0.04, a=41.57, b=-0.28$, for the two regressions respectively). There was no apparent relationship between mean fragment size and number of fragments reattached $\left(r^{2}=0.02, a=7.02, b=-0.02\right)$. Thus the percentage of fragments reattaching was not predicted by either size or abundance of the fragments, even though the actual number of fragments reattaching was correlated with the total number of fragments (Fig. 3). 
Discussion. The percentage reattachment of Millepora complanata is comparable to the percentages for the corals Acropora palmata ( $39 \%$ ) and A. cervicornis and Porites furcata (46 to $48 \%$ ) (Highsmith et al. 1980). However, the hypothesis that survival of coral fragments is size-dependent is not supported by the data for distribution of the calcareous hydrozoan $M$. complanata. No significant correlation was found between percentage of millepore fragments reattached and mean fragment size.

Although fragmentation may be simply an inevitable consequence of being a relatively large, calcareous, vertically growing organism living in wave-exposed habitats, there are a number of factors other than size which may influence the success of attachment. The positive relation between the number of quadrats containing Millepora complanata and the abundance of reattached fragments may be partly dependent on the density of living colonies per unit area. Dense packing of growing colonies may increase survival by trapping broken fragments between upright blades.

Morphology as well as size influenced the survival of fragmented corals. Tunnicliffe (1981) and Highsmith (1982) noted that fragment shapes most favourable for reattachment were those developed in 3 dimensions. The tendency towards sphericity in the coral Siderastrea radians improved the chances of corallum survival (Lewis 1989a). The bladed form Millepora complanata fragment would not offer the advantages for survival found in branching corals but would reduce the chance of dislodgement when lying flat on the substratum. The small number of fragments found in the reef channels suggests their retention on the surface of the reef spurs.

The ability to regenerate tissue quickly from broken and separated coral fragments has been emphasized by Bak et al. (1977) and Loya (1976) as being very important in the recovery of damaged reefs. Very little appears to be known about the regenerative capacity of millepores. Fishelson (1973) found that Millepora dichotoma damaged by low tides in the Red Sea was able to regenerate readily, and storm-damaged millepores in the Caribbean recovered rapidly (Stoddart 1974). On the other hand, millepores in Florida did not readily regenerate lesions produced by the predatory worm Hermodice carunculata (Witman 1988).

The high survival rate of Millepora complanata fragments suggests a selective advantage to fragmentation. The importance of fragmentation as a mode of reproduction depends upon its frequency. Because the risk of breakage increases with size (Denny et al. 1985) there should be an advantage to increasing colony size in the population. Blade colonies thicken with age. Therefore, thinner, younger tips are more likely to break than bases. Furthermore, millepores do not appear to be subject to the intense burrowing and bioerosion that affect the Scleractinia (Lewis 1989b), thus favouring the survival of stumps for regeneration. Selection for breakage may also explain the orientation of blades of living colonies broadside to the prevailing direction of breaking waves.

Acknowledgements. This work was supported by a Grant in Aid of Research from the Natural Science and Engineering Research Council of Canada. I am grateful to Dr Wayne Hunte for the use of facilities at the Bellairs Research Institute of McGill University in Barbados and to Geoff Beck for assistance in the field.

\section{LITERATURE CITED}

Bak, R. P. M., Brouns, J. J. W. M., Heys, F. M. L. (1977) Regeneration and aspects of spatial competition in the scleractinian corals Agaricia agaricites and Montastrea annularis. Proc. 3rd int. coral Reef Symp. 1: 143-148

Boschma, H. (1948). The species problem in Millepora. Zool. Verh., Leiden 1: 3-115

Connell, J. H. (1973). Population ecology of reef building corals. In: Jones, O. A., Endean, R. (eds.) Biology and geology of coral reefs, Vol. 2, Biology, Part 1. Academic Press, New York, p. 205-245

Denny, W W., Daniel, T. L., Koehl, M. A. R. (1985). Mechanical limits to size in wave swept organisms. Ecol. Monogr 55: 69-102

Dollar, S. J., (1982). Wave stress and coral community structure in Hawaii. Coral Reefs 1: 71-81

Fishelson, L. (1973). Ecology of coral reefs in the Gulf of Aqaba (Red Sea) influenced by pollution. Oecologia 12: $55-67$

Highsmith, R. C. (1980). Passive colonization and asexual colony multiplication in the massive coral Porites lutea Milne Edwards. J. exp. mar. Biol. Ecol. 47: 55-67

Highsmith, R. C. (1982). Reproduction by fragmentation in corals. Mar Ecol. Prog. Ser. 7: 207-226

Highsmith, R. C., Riggs, A. C., D'Antonio, C. M. (1980). Survi$\mathrm{val}$ of hurricane-generated coral fragments and a disturbance model of reef-calcification/growth rates. Oecologia 46: $322-329$

Hughes, R. N. (1989). A functional biology of clonal animals Chapman \& Hall, London

Hughes, T P., Jackson, J. B. C. (1985). Population dynamics and life histories of foliaceous corals. Ecol. Monogr 55: $141-166$

Lewis, J. B. (1989a). Spherical growth in the Caribbean coral Siderastrea radians (Pallas) and its survival in disturbed habitats. Coral Reefs 7: 161-167

Lewis, J. B. (1989b). The ecology of Millepora: a review. Coral Reefs 8: 99-107

Loya, Y. (1976). Skeletal regeneration in a Red Sea scleractinian coral population. Nature, Lond. 261: 490-491

Mah, A. J., Stearn, C. W. (1986). The effect of Hurricane Allen on the Bellairs fringing reef, Barbados. Coral Reefs 4: $169-176$

Rogers, C. S., Suchanek, T. H., Pecora, F. A. (1982). Effects of hurricanes David and Frederick (1979) on shallow Acropora palmata reef communities: St. Croix, U.S. Virgin Islands. Bull. mar. Sci. 32: 532-548

Stearn, C. W., Riding, R. (1973). Forms of the hydrozoan Millepora on a recent coral reef. Lethaia 6: 187-200 
Stearn, C. W., Scoffin, T. P., Martindale, W. (1977). Calcium carbonate budget of a fringing reef on the west coast of Barbados, part I: Zonation and productivity. Bull. mar. Sci. 27: 479-510

Stoddart, D. R. (1974). Post-hurricane changes on the British Honduras reefs: resurvey of 1972 . Proc. 2 nd int. coral Reef Symp. 2: 473-483

Tomascik, T., Sander, F. (1985). Effects of eutrophication on reef-building corals. I. Growth rate of the reef-building coral Montastrea annularis. Mar. Biol. 87: 143-1.55

Tunnicliffe, V (1980). Biological and physical processes

This note was submitted to the editor affecting the survival of a stony coral, Acropora cervicornis. Ph.D. thesis, Yale University, New Haven

Tunnicliffe, $V$ (1981). Breakage and propagation of the stony coral Actopora cervicornis. Proc natn. Acad. Sci. U.S.A. 78: $2427-2431$

Witman, J. D. (1988). Effects of predation by the fireworm Hermodice carunculata on Milleporid corals. Bull. mar. Sci. 42: $446-458$

Woodley, J. D., and 19 others (1981). Hurricane Allen's impact on Jamaican coral reefs. Science 214: 749-755

Manuscript received: July 18, 1990

Accepted: November 29, 1990 